\title{
Individual deprivation, regional deprivation, and risk for oral clefts in Argentina
}

\author{
Mariela Soledad Pawluk, ${ }^{1}$ Hebe Campaña, ${ }^{1}$ Monica Rittler, ${ }^{2}$ Fernando Adrián \\ Poletta, ${ }^{1}$ Viviana R. Cosentino, ${ }^{1}$ Juan Antonio Gili, ${ }^{1}$ Lucas Gabriel Gimenez, ${ }^{1}$ and \\ Jorge Santiago López Camelo'
}

Suggested citation Pawluk MS, Campaña H, Rittler M, Poletta FA, Cosentino VR, Gili JA, et al. Individual deprivation, regional deprivation, and risk for oral clefts in Argentina. Rev Panam Salud Publica. 2017; 41:e110.

\begin{abstract}
Objective. The aim of this study was to analyze the effects of individual low socioeconomic status (SES) and deprived geographical area (GA) on the occurrence of isolated cleft lip with or without cleft palate $(C L \pm P)$ in Argentina.

Methods. This case-control study included 577 newborns with isolated CL $\pm P$ and 13344 healthy controls, born between 1992 and 2001, from a total population of 546129 births in 39 hospitals in Argentina. Census data on unsatisfied basic needs were used to establish the degree of geographical area deprivation. An SES index for each individual was established, using maternal age, gravidity, low paternal and maternal education, and low-level paternal occupation. Logistic regression was used to assess the effects of low SES and of deprived GA on $C L \pm P$.

Results. A slightly increased risk of $C L \pm P$ was observed in mothers with a low SES, while a deprived GA showed no effect. Native ancestry, acute maternal illnesses, and poor prenatal care were significant risk factors for $C L \pm P$ for the mothers with low SES, after using propensity scores to adjust for the demographic characteristics in cases and controls.

Conclusions. Low individual SES slightly increased the risk for $C L \pm P$, but a deprived $G A$ did not have that effect. There was no interaction between individual SES and deprived GA. Factors related to low individual SES-including poor prenatal care, low parental education, lack of information, and lifestyle factors-should be primarily targeted as risk factors for $C L \pm P$ rather than factors related to a deprived place of residence.
\end{abstract}

Keywords Cleft lip; cleft palate; social class; Argentina.

Cleft lip with or without cleft palate $(\mathrm{CL} \pm \mathrm{P})$ is among the most prevalent congenital anomalies. In Argentina, for

\footnotetext{
Estudio Colaborativo Latinoamericano de Malformaciones Congénitas (ECLAMC), Laboratorio de Epidemiología Genética, Centro de Educación Médica e Investigaciones Clínicas (CEMIC-CONICET), Buenos Aires, Argentina. Send correspondence to Mariela Soledad Pawluk, at m_s_pawluk@outlook.com

2 Estudio Colaborativo Latinoamericano de Malformaciones Congénitas (ECLAMC), Hospital Materno Infantil Ramón Sarda, Buenos Aires, Argentina.
}

example, it affects approximately 1 in 1000 newborns (1). A wide variety of studies have attempted to identify the impact of socioeconomic status (SES) on adverse outcomes, particularly perinatal ones. Some studies have suggested that low SES is associated with an increased risk for neural tube defects $(2,3)$. For orofacial clefts, some studies have found a similar increase in risk (4-7), but other research has not (8-10). Using the Carstairs and Morris deprivation index (11),
Clark et al. (12) showed an increased frequency of oral clefts in neighborhoods with the highest level of deprivation. Other researchers have found an association between low maternal SES and the rate of orofacial clefts (13).

Poletta et al. (14) identified two CL $\pm \mathrm{P}$ clusters coinciding with deprived geographical areas (GAs) in Argentina. This finding could be related to typical conditions found in poor regions, including certain environmental factors 
(pesticides, poor water quality, dietary deficiencies, environmental pollution); low individual SES; and a high rate of Amerindian ancestry. Together with descendants of Europeans, persons of Amerindian heritage comprise the majority of Argentinians. A greater genetic susceptibility for $\mathrm{CL} \pm \mathrm{P}$ and a low socioeconomic status are both recognizably associated with Amerindian ancestry $(15,16)$.

The objective of this study was to assess the risk for isolated $\mathrm{CL} \pm \mathrm{P}$ in infants of mothers of low SES who live in a deprived GA, by quantifying the effect of both of those characteristics. The time period that we selected for our research, 1992 through 2001, was based on the fact that Argentina has had critical economic fluctuations over the last two decades. This included a recession from 1995 to 2002, when unemployment and poverty rates increased greatly and the currency was devalued (17).

The health conditions of people living in deprived GAs may be influenced by such risk factors as limited access to health services and medication, insufficient medical equipment and training of health workers, prevailing attitudes towards health, lack of social support, and deficient public health policy (18). Particularly for $\mathrm{CL} \pm \mathrm{P}$, each risk factor could contribute in a direct or indirect way through variables mediating or interacting among these risk factors. Identifying and quantifying the contribution of low SES and of deprived GA could provide health authorities with resources for primary prevention of $\mathrm{CL} \pm \mathrm{P}$ and other adverse outcomes.

\section{MATERIALS AND METHODS}

For our work, we used a case-control study design to assess the odds ratios of deprived GAs and low SES for isolated $\mathrm{CL} \pm \mathrm{P}$.

The data for our study came from information on Argentina compiled by the Latin American Collaborative Study of Congenital Malformations (ECLAMC). ECLAMC is a hospital-based registry of congenital malformations in South America. It involves the voluntary collaboration of health professionals (mostly pediatricians) within a network of maternity hospitals. Those professionals register data on over 50 risk factors and demographic characteristics, previous birth outcomes, and prenatal factors, by obtaining information from medical records and by interviewing the mother of a malformed infant and the mother of a healthy control (a nonmalformed infant that is born immediately after each affected newborn and that is paired by sex), before their discharge. Detailed descriptions of the ECLAMC registry and its methodology have been previously published (19).

Following the standard ECLAMC procedures, the demographic data and informed consent for our study were obtained by health professionals through interviews with the mothers before discharge (19).

Our study was approved by the Centro de Educación Médica e Investigaciones Clínica (CEMIC) Institutional Review Board (Office for Human Research Protection, U.S. Department of Health and Human Services, IRB00001745-IORG 0001315).

In Argentina, during the period of 1992 through 2001, a total of 13344 malformed newborns were registered by ECLAMC in 546129 births occurring in 39 hospitals. From those 13344 malformed children, we selected out 850 live and stillborn infants with $\mathrm{CL} \pm \mathrm{P}$. After we excluded stillborn babies and those with multiple anomalies or syndromes, 577 live-borns with isolated $\mathrm{CL} \pm \mathrm{P}$ remained. For our analysis, we used data on 13344 healthy controls born during that same time period.

\section{Geographic deprivation level}

Our sample was recruited from 39 hospitals of Argentina and may not necessarily be representative of the entire population. Representativeness varies in the country because of differences in how many departments are represented in each sample. (The provinces of Argentina are divided into departments (departamentos), except for the province of Buenos Aires, which is divided into partidos. In this article, the word "department(s)" will be used as the general term unless referring specifically to just the province of Buenos Aires.)

While generalizability is less certain at the country level, it is rather high at the city level. Many ECLAMC hospitals are considered large community hospitals that together cover a relatively large percentage of births in their respective department. According to national census data for Argentina, in 2001, the country had a total population of 36260130 , and there were 683495 live births (20). Our analytical sample is obviously a small fraction of the total number of births in these hospitals; nonetheless, this indicates that the ECLAMC hospitals from which our sample is selected are major providers of maternity care in their communities. The representativeness ranges from as high as 97\% (as in department of San Miguel de Tucumán) to as low as $10 \%$ (as in the partido of Lomas de Zamora, in the province of Buenos Aires) (Appendix I).

To identify deprived GAs, we used national census data on unsatisfied basic needs (UBN) (21) of the same period (1992-2001), for the 25 departments in Argentina where the 39 ECLAMC participating maternity hospitals are located, represented by their geographical coordinates (latitude and longitude). The UBN index data were obtained from the 2001 National Population, Household, and Housing Census (20). This national index is used to measure poverty by expressing the percentage of households with unsatisfied basic needs in each department. Its indicators are directly related to four areas of basic needs (housing, health services, basic education, and minimum income), and it comprises four dimensions. The basic needs of each dimension are considered unsatisfied if any one of the following criteria is fulfilled:

A. Dwelling quality: 1: Housing: dwelling is in bad conditions in terms of quality and condition of housing materials; 2: Crowding: More than three residents per bedroom.

B. Water and sewage: 1: The dwelling is not connected to the public water network; 2: The dwelling is not connected to the public sewer system.

C. Childhood education: Children aged between 6 and 12 years do not attend school.

D. Subsistence capacity: 1: Four or more people residing in the dwelling per working person; 2: Completed education of the head of the household is two or fewer years of primary school.

We used a Kuldorff spatial scan statistic under the Poisson model (22) to determine geographical areas with statistically significant low or high UBN index values as compared to the mean value of the 
total Argentinian population. Using the precise location of each hospital as defined by its geographical coordinates (latitude and longitude), this analysis tests a circular area centered at each point, and each point represents 1 of the 39 maternity hospitals (i.e., unit of analysis) in the ECLAMC network. (The maternal home address could not be used, since this variable was not specified in more than $50 \%$ of the sample. Therefore, the hospital of birth was used as a proxy for maternal residence.)

The null hypothesis states that the UBN index is homogeneous in the whole sample, and the alternative assumes deprivation or nondeprivation within a given area, as compared with the UBN index observed outside that area. This test uses the maximum likelihood ratio to determine the areas with the smallest probability for the observed unusual UBN index. The $P$ value was obtained through multiple simulations by the Monte Carlo model of 999 replications. Cluster regions were not established a priori. Our analysis had two conditions: the radius of the cluster had to be smaller than $500 \mathrm{~km}$, and the resulting areas should not overlap.

\section{Individual-level socioeconomic status}

A confirmatory factor analysis was performed to establish the latent variable SES as a proxy for individual SES. This variable was composed of seven directly observed, binomial variables: 1) maternal age $\leq 19$ years; 2 ) maternal age $\geq 35$ years; 3) maternal primigravidity; 4) multigravidity (three or more pregnancies); 5) low paternal education (from no schooling to incomplete grammar school); 6) low maternal education (also from no schooling to incomplete grammar school); and 7) low-level paternal occupation (unemployed, househusband, or odd job/unskilled labor).

We used LISREL 8.80 software (Scientific Software International, Inc., Chicago, Illinois, United States of America) for structural equation modeling to evaluate different models. The model that best adjusted was: low maternal age, multigravidity, low paternal and maternal education, and low-level paternal occupation. Scores were estimated for each newborn's family. The 75th percentile was used to classify families, creating two groups: a) families of low SES and b) families of medium or high SES. For simplicity, the second group was called families "of not-low SES."

The following variables, based on maternal self-reports, were analyzed as possible confounders: few prenatal visits (fewer than five); acute and chronic maternal illnesses; maternal medication (any medicine use during the first trimester of pregnancy (yes/no)); and "native ancestry." ("Native ancestry" was defined as the lack of recognized ancestors from outside Latin America. That is, the mother only knew about specific child ancestors who were born in Latin America, as far back as she could remember (generally up to great great-grandparents). As measured, native-only ancestry does not necessarily mean indigenous ancestry. Indeed, for the majority of children, native-only ancestry indicates that all the child's ancestors whom the mother can remember were born in Latin America.)

\section{Statistical analyses}

A Poisson regression was used to estimate the $\mathrm{CL} \pm \mathrm{P}$ frequency, according to geographical deprivation level. Logistic regression, using information on mothers of control newborns, was carried out to assess the risk factors in deprived GAs. The GA of maternal residence (deprived GA or not-deprived GA) was the dependent variable, while the independent variables were the confounders defined above.

Odds ratios (ORs) and 95\% confidential intervals (CIs) were used to estimate the risk of low SES in deprived areas and in not-deprived areas. ORs were compared with a Mantel-Haenszel test, to evaluate any interaction between risk factors and deprived GA.

Logistic regression was used to assess the adjusted effects of low SES in deprived and not-deprived areas.

Propensity scores were calculated in order to balance the demographic characteristics of cases and controls, thereby assessing the residual effect of low SES in deprived GAs (Appendix II). The propensity scores were incorporated in the model as dummy variables. The following logistic regression model was evaluated:

$P\left(\frac{Y}{x}\right)=\frac{1}{e^{-a 1 L o w S E S+a 2 G e o D e p+\Sigma a 3 i X i+\Sigma a 4 i b i+\Sigma a 5 i \text { year } i}}$

In this model, a1 is the coefficient of low SES mothers; a2 is the coefficient of deprived geographic areas; $a 3_{i}$ is the coefficients of $\mathrm{X}$ i risk factors; $\mathrm{a} 4_{\mathrm{i}} \mathrm{b}_{\mathrm{i}}$ is the coefficients of dummy variables propensity scores; and $\mathrm{a} 5_{\mathrm{i}}$ is the coefficients of dummy variables of year $_{i}$, for each year of the 1992-2001 period.

The sample size was calculated based on a $20 \%$ low-SES prevalence. The 577 cases and 13344 controls used in this study made it possible to identify a minimum OR of 1.50 , for an $80 \%$ power of the test $(\beta=0.20)$ and a type I error of $\alpha<0.05$.

\section{RESULTS}

\section{Cluster analysis}

The Kuldorff analysis identified three geographic clusters with significantly high UBN index values (GAs 1, 2, and 3) and one GA with a significantly low UBN index value (GA 4) (Table 1). Cluster 5 represented the remaining departments, with a medium UBN index value.

The three clusters with high UBN index values were then grouped into a single cluster called "deprived GAs," while the two clusters with low UBN index values (Cluster 4 and Cluster 5) were grouped into another cluster, called "notdeprived GAs."

The frequency of $\mathrm{CL} \pm \mathrm{P}$ was 8.2 per 10000 births (95\% CI: 6.5, 10.2) in not-deprived GAs and 12.3 per 10000 (95\% CI: $10.8,13.9)$ in deprived GAs, where it increased with increasing GA deprivation (incidence rate ratio $=1.28, P=0.023$ ) . The CL $\pm \mathrm{P}$ prevalence of the three clusters of deprived GAs was significantly higher than that of the remaining departments (GA 5).

\section{Individual socioeconomic status}

The factor analysis for the construction of individual SES values, including young maternal age, multigravidity, low maternal and paternal education, and low-level paternal occupation, had a goodness of fit of $\chi^{2} 1 \mathrm{df}=0.11, P=0.739$. The residual between observed and expected data had a root mean square error of approximation (RMSEA) of 0.022 (95\% CI: 0.011, 0.036). According to the distribution of the SES scores, the mothers were divided into those of low SES $\left(\geq 75^{\text {th }}\right.$ percentile) and those of not-low SES.

Among the demographic characteristics more common among those living in deprived geographical areas were low SES, native ancestry, maternal acute 
TABLE 1. Geographical areas (GAs) by location, number of hospitals, population, unsatisfied basic needs (UBN) index, and rate (per 10000 births) of cleft lip with or without cleft palate (CL士P), with 95\% confidence interval (Cl), Argentina, 1992-2001

\begin{tabular}{|c|c|c|c|c|c|c|c|c|c|c|c|}
\hline GA & Name & Department(s) & Latitude & Longitude & $\begin{array}{c}\text { No. of } \\
\text { hospitals }\end{array}$ & $\begin{array}{c}\text { Population of } \\
\text { GA }\end{array}$ & UBN (\%) & Births & No. of $C L \pm P$ & $\mathrm{CL} \pm \mathrm{P}$ rate & $95 \% \mathrm{Cl}$ \\
\hline 1 & & Futaleufu & $425449 \mathrm{~S}$ & 7118390 & 1 & & & & & & \\
\hline 2 & & $\begin{array}{l}\text { Lomas de } \\
\text { Zamora }\end{array}$ & $344551 \mathrm{~S}$ & 5825440 & 1 & & & & & & \\
\hline \multirow[t]{3}{*}{3} & North-West & $\begin{array}{l}\text { Manuel } \\
\text { Belgrano }\end{array}$ & $241113 \mathrm{~S}$ & 6517570 & 2 & 905315 & 18.4 & 132266 & 158 & 11.9 & $10.2-14.0$ \\
\hline & & $\begin{array}{l}\text { San Miguel } \\
\text { de Tucumán }\end{array}$ & $264950 \mathrm{~S}$ & 6512130 & 1 & & & & & & \\
\hline & & La Rioja & $292447 \mathrm{~S}$ & 6651210 & 1 & & & & & & \\
\hline 4 & Buenos Aires City & Buenos Aires & $343630 \mathrm{~S}$ & 5822190 & 5 & 2725488 & 7.8 & 97408 & 80 & 8.2 & $6.5-10.2$ \\
\hline
\end{tabular}

Source: Prepared by the authors from the study data.

a $\mathrm{NA}=$ not applicable.

TABLE 2. Demographic characteristics, with $95 \%$ confidence intervals (Cls), in deprived geographic areas (GAs) and not-deprived GAs of Argentina, 1992-2001

\begin{tabular}{|c|c|c|c|c|c|c|}
\hline \multirow{2}{*}{ Risk factor } & \multicolumn{3}{|c|}{ Deprived GAs $(N=11106)$} & \multicolumn{3}{|c|}{ Not-deprived GAs ( $N=2338)$} \\
\hline & $N$ & $\%$ & $95 \% \mathrm{Cl}^{\mathrm{a}}$ & $N$ & $\%$ & $95 \% \mathrm{Cl}$ \\
\hline Maternal age $\leq 19$ & 2336 & 21.2 & $20.3-21.8$ & 367 & 15.7 & $14.2-17.2$ \\
\hline Maternal age $\geq 35$ & 1247 & 11.3 & $10.6-11.8$ & 268 & 11.5 & $10.2-12.8$ \\
\hline Primigravidity & 2939 & 26.7 & $25.6-27.3$ & 855 & 36.6 & $34.6-38.6$ \\
\hline Multigravidity > 3 & 3878 & 34.9 & $34.0-35.8$ & 497 & 21.3 & $19.6-23.0$ \\
\hline Low maternal education & 2272 & 20.6 & $19.7-21.2$ & 166 & 7.1 & $6.1-8.2$ \\
\hline Low paternal education & 2089 & 19.0 & $18.1-19.5$ & 120 & 5.1 & $4.3-6.1$ \\
\hline Low-level paternal occupation & 4700 & 42.3 & $41.4-43.2$ & 619 & 26.5 & $24.7-28.3$ \\
\hline Low socioeconomic status. & 7797 & 70.8 & $69.3-71.1$ & 1004 & 42.9 & $40.9-45.0$ \\
\hline Native ancestry & 9603 & 87.3 & $85.8-87.1$ & 1916 & 82.0 & $80.3-83.5$ \\
\hline Maternal acute illness & 3187 & 29.0 & $27.9-29.5$ & 530 & 22.7 & $21.0-24.4$ \\
\hline Maternal chronic disease & 1310 & 11.9 & $11.2-12.4$ & 383 & 16.4 & $14.9-17.9$ \\
\hline Maternal medication & 4975 & 45.2 & $43.9-45.7$ & 1141 & 48.8 & $46.8-50.8$ \\
\hline Prenatal visits < 5 & 2813 & 25.6 & $24.5-26.1$ & 252 & 10.8 & $9.5-12.1$ \\
\hline
\end{tabular}

Source: Prepared by the authors from the study data.

illnesses, and fewer prenatal visits. On the other hand, their frequencies of chronic diseases and of first trimester medication were lower (Table 2).

\section{Low socioeconomic status and other risk factors for cleft lip with or without cleft palate}

Table 3 shows the number of cases and controls and the frequency of exposure to risk factors in the deprived areas and in the not-deprived areas. The univariate analysis showed that low SES, native ancestry, acute and chronic maternal illnesses, maternal medication, and few prenatal visits were risk factors for $\mathrm{CL} \pm \mathrm{P}$ in deprived GAs. In contrast, in not-deprived GAs, only three variables were of risk: maternal acute illnesses, maternal medication, and few prenatal visits. There were no significant OR differences between the deprived GAs and the not-deprived GAs, thereby excluding any interaction between risk factors and GA deprivation (Table 3).

Five propensity score strata were defined, and their distribution is shown in Appendix II. After incorporating propensity scores to adjust for SES as well as years as dummy variables in the model, a slight residual risk for $\mathrm{CL} \pm \mathrm{P}$ remained from low SES and native ancestry, while maternal acute illnesses and few prenatal visits showed significant odds ratios. No effect of GA deprivation was observed (Table 4).

\section{DISCUSION}

Since the objective of the study was to analyze the impact of poverty on $\mathrm{CL} \pm \mathrm{P}$, we selected the 1992-2001 period to study the births occurring in Argentina. Argentina suffered an economic downturn that began in late 1998 and intensified in 2001 and 2002, with Argentina's gross domestic product declining and the unemployment rate increasing (17).

Two poverty indicators were used in this study: 1) a national population index of unsatisfied basic needs (UBN), to evaluate adverse social conditions in Argentina related to maternal residence, and 2) socioeconomic status (SES), to assess poverty at an individual level. In order to evaluate unmeasured variables related to SES, we created an index that fitted the observed correlation matrix. This index included variables related to SES in South America, such as parental age and education, gravidity, and paternal occupation (23). The use of an index to measure SES provides statistical efficiency and a simple presentation of results. In contrast, several single measurements "may lead to collinearity and cluttered results, especially when the intention is to reflect a single significant concept, such as SES, rather than examining the unique contribution of each component," according to Wehby and colleagues (17). 
TABLE 3. Univariate analysis of risk factors for cleft lip with or without cleft palate $(C L \pm P)$ in deprived and not-deprived geographic areas (GAs) of Argentina, 1992-2001

\begin{tabular}{|c|c|c|c|c|c|c|c|c|c|c|c|c|c|c|}
\hline \multirow{3}{*}{ Risk factor } & \multicolumn{6}{|c|}{ Deprived GAs } & \multicolumn{6}{|c|}{ Not-deprived GAs } & & \\
\hline & \multicolumn{2}{|c|}{ Cases $(N=497)$} & \multicolumn{2}{|c|}{$\begin{array}{c}\text { Controls } \\
(N=11006)\end{array}$} & \multirow{2}{*}{$\mathrm{OR}$} & \multirow{2}{*}{$P$} & \multicolumn{2}{|c|}{ Cases $(N=80)$} & \multicolumn{2}{|c|}{$\begin{array}{c}\text { Controls } \\
(N=2338)\end{array}$} & \multirow{2}{*}{$\mathrm{OR}$} & \multirow[t]{2}{*}{$P$} & \multicolumn{2}{|c|}{ Heterogeneity } \\
\hline & Exposed & $\%$ & Exposed & $\%$ & & & Exposed & $\%$ & Exposed & $\%$ & & & $\chi^{2}(1 \mathrm{df})$ & $P$ \\
\hline Native ancestry & 441 & 88.7 & 9603 & 87.3 & 1.52 & 0.014 & 63 & 78.8 & 1916 & 82.0 & 0.91 & 0.740 & 2.35 & 0.126 \\
\hline Maternal acute illness & 175 & 35.2 & 3187 & 29.0 & 1.40 & 0.001 & 30 & 37.5 & 530 & 22.7 & 2.09 & 0.002 & 2.45 & 0.117 \\
\hline Maternal chronic disease & 70 & 14.1 & 1310 & 11.9 & 1.26 & 0.076 & 15 & 18.8 & 383 & 16.4 & 1.19 & 0.544 & 0.03 & 0.857 \\
\hline Prenatal visits $<5$ & 173 & 34.8 & 2813 & 25.6 & 1.69 & 0.000 & 16 & 20.0 & 252 & 10.8 & 1.94 & 0.024 & 0.18 & 0.671 \\
\hline
\end{tabular}

Source: Prepared by the authors from the study data.

TABLE 4. Low socioeconomic status, deprived geographic area, and other risk factors for cleft lip with or without cleft palate (adjusted by years and propensity scores), Argentina, 1992-2001

\begin{tabular}{|c|c|c|c|c|}
\hline Risk factor & $O R^{a}$ & \multicolumn{2}{|c|}{$95 \% \mathrm{Cl}^{\mathrm{b}}$} & $P$ \\
\hline Low socioeconomic status & 1.23 & 0.96 & 1.58 & 0.097 \\
\hline Deprived geographic area & 1.00 & 0.75 & 1.35 & 0.983 \\
\hline Native ancestry & 1.44 & 0.98 & 2.11 & 0.060 \\
\hline Maternal acute illness & 1.45 & 1.12 & 1.88 & 0.005 \\
\hline Maternal chronic disease & 1.19 & 0.86 & 1.63 & 0.290 \\
\hline Maternal medication & 1.08 & 0.85 & 1.38 & 0.535 \\
\hline Prenatal visits $<5$ & 1.68 & 1.33 & 2.12 & $<0.001$ \\
\hline
\end{tabular}

Source: Prepared by the authors from the study data.

${ }^{\mathrm{a}} \mathrm{OR}=$ odds ratio.

${ }^{\mathrm{b}} \mathrm{Cl}=$ confidence interval.

As expected, our results showed that populations with the most unfavorable social conditions resided in deprived geographic regions. Pregnant women in these areas had fewer prenatal control visits and more acute illnesses, and the women were also more often of native ancestry. Given the recognized high prevalence of $\mathrm{CL} \pm \mathrm{P}$ in Amerindian populations (16), this last observation could explain the high frequency of $\mathrm{CL} \pm \mathrm{P}$ we found in clusters of deprived areas.

No difference between ORs for low SES and the rest of the risk factors was observed in deprived areas versus not-deprived areas, indicating absence of interaction between risk factors and area of residence.

Propensity scores were used in the final model to evaluate the residual effects of unmeasured variables. An increased risk for $\mathrm{CL} \pm \mathrm{P}$ observed in low-SES women $(\mathrm{OR}=1.23)$ could not be explained by any single variable incorporated in the SES index. The slightly greater risk found might be due to residual effects of other factors correlated with low SES, such as environmental conditions (24-26), smoking $(7,27)$, alcohol $(6)$, and malnutrition.

A number of similar studies have been performed, with differing results.
Carmichael et al. (28) found no risk of individual SES with oral clefts. In a population-based study, Ericson et al. (29) observed the greatest risk of $\mathrm{CL} \pm \mathrm{P}$ for subjects with the lowest SES, based on a multilevel index that combined individual and neighborhood measures. Yang et al. (30) showed consistently increased risks of selected birth defects associated with a low household SES index, but not with individual SES measures.

Whether or not the effects on health due to geographical deprivation and individual socioeconomic status are independent is still a controversial issue in the scientific literature (31). In general, successive adjustments for individual SES progressively reduce the magnitude of the association between GA deprivation and health (32). This shows that variables associated with low SES, at the individual level, are more relevant to adverse reproductive health than are variables related to the place of residence. It is unclear if there is an actual independent neighborhood effect or if an incomplete adjustment of individual SES is responsible for the small residual differences between residential areas (33).
Among all the variables we analyzed in our study, a reduced number of prenatal visits was the most important risk factor for $\mathrm{CL} \pm \mathrm{P}$. In addition, we observed a higher proportion of mothers with few prenatal visits in deprived GAs than in other areas.

There is a well-known association between poor prenatal care and such adverse reproductive outcomes as low birthweight, prematurity, and increased mortality (34). A study of newborns in South America and in the United States showed that adequate prenatal care was associated with larger birthweight increases in infants with $\mathrm{CL} \pm \mathrm{P}$ than in healthy newborns (35). Given that low birthweight is a well-recognized comorbidity of $\mathrm{CL} \pm \mathrm{P}$, prenatal care for at-risk pregnancies is relevant to reducing the health burden of $C L \pm P$.

\section{Strengths and limitations}

Our study sample included all of the cases and the controls born in 39 ECLAMC hospitals in Argentina, so a selection bias was unlikely.

Since the data on the maternal home address were unspecified in more than $50 \%$ of the sample, we used the hospital of birth as a proxy for maternal residence during pregnancy. This could have introduced bias in the exposure estimates, but we assume that most of cases were born in a hospital within a short distance of the maternal residence. This could have caused some bias with respect to the referral of cases with a prenatal diagnosis to tertiary centers outside the department of residence. However, since such a prenatal diagnosis for isolated $\mathrm{CL} \pm \mathrm{P}$ is relatively rare, any such referral bias should have been modest. 
In the ECLAMC work, the descriptions of congenital anomalies are reviewed by expert geneticists. The personal interviews with mothers are conducted by a qualified and experienced team. Before beginning to do data collection, all ECLAMC-affiliated professionals receive the same standard training from ECLAMC coordinators. Annual ECLAMC meetings are held, where further training is provided as needed. As a result, data quality and consistency are thought to be high. Nevertheless, maternal memory is an important caveat in casecontrol studies, and it is well known that exposure factors are more often reported for malformed newborns than for healthy ones. Therefore, despite the ECLAMC training, this type of bias cannot be discarded.

There is socioeconomic diversity among the areas where the ECLAMC hospitals included in this study are located. This makes it possible to compare regions with different deprivation levels and thus evaluate the impact of access to health services and of infrastructure quality.

Finally, unrecognized factors or unmeasured variables, due to unavailable data, could have affected our results. To control these potential biases, we applied a propensity score, which balanced the demographic characteristics of the cases and controls in our study.

\section{Conclusions}

This study showed that, after adjusting for confounders, low SES is a slight risk factor for $\mathrm{CL} \pm \mathrm{P}$, independent of the geographical deprivation level. No interaction between individual SES and deprived GA was found. The number of prenatal visits differed across geographical deprivations levels, probably indicating limited access to health services in more deprived regions.

These results could be a guide for public health policies, indicating that factors related to low individual SES, such as poor education and prenatal control, as well as lifestyle factors, such as smoking and alcohol, should be primarily targeted as risk factors for $C L \pm P$, rather than those related to a deprived place of residence.

Acknowledgments. The authors wish to thank all the people working cooperatively in ECLAMC, a network that has been active for more than 40 years.

Funding. Support came from the Consejo Nacional de Investigaciones Científicas y Técnicas (CONICET) of Argentina and from the Scientific Research Commission of Buenos Aires (CICPBA).

Conflicts of Interest. None declared.

Disclaimer. Authors hold sole responsibility for the views expressed in the manuscript, which may not necessarily reflect the opinion or policy of the RPSP/ PAJPH or PAHO.

\section{REFERENCES}

1. Campaña H, Pawluk MS, López Camelo JS; Grupo de Estudio del ECLAMC. Prevalencia al nacimiento de 27 anomalías congénitas seleccionadas, en 7 regiones geográficas de la Argentina [Birth prevalence of 27 selected congenital anomalies in 7 geographic regions of Argentina]. Arch Argent Pediatr. 2010;108(5):409-17.

2. Bound JP, Harvey PW, Francis BJ, Awwad F, Gatrell AC. Involvement of deprivation and environmental lead in neural tube defects: a matched case-control study. Arch Dis Child. 1997;76(2):107-12.

3. Wasserman CR, Shaw GM, Selvin S, Gould JB, Syme SL. Socioeconomic status, neighborhood social conditions, and neural tube defects. Am J Public Health. 1998;88(11):1674-80.

4. Saxen I. Cleft lip and palate in Finland: parental histories, course of pregnancy and selected environmental factors. Int J Epidemiol. 1974;3(3):263-70.

5. Hemminki K, Mutanen P, Luoma K, Saloniemi I. Congenital malformations by the parental occupation in Finland. Int Arch Occup Environ Health. 1980;46(2): 93-8.

6. Munger RG, Romitti PA, Daack-Hirsch S, Burns TL, Murray JC, Hanson J. Maternal alcohol use and risk of orofacial cleft birth defects. Teratology. 1996;54(1):27-33.

7. Lieff S, Olshan AF, Werler M, Strauss RP, Smith J, Mitchell A. Maternal cigarette smoking during pregnancy and risk of oral clefts in newborns. Am J Epidemiol. 1999;150(7):683-94.
8. Czeizel A. Studies of cleft lip and cleft palate in East European populations. In: Melnick M, Bixler D, Shields ED, eds. Etiology of cleft lip and palate. New York: Alan R. Liss, Inc.;1980:249-96.

9. Vrijheid M, Dolk H, Stone D, Abramsky L, Alberman E, Scott JE. Socioeconomic inequalities in risk of congenital anomaly. Arch Dis Child. 2000;82(5):349-52.

10. Kallen K. Maternal smoking and orofacial clefts. Cleft Palate-Cran J. 1997;34(1):11-6.

11. Carstairs V, Morris R. Deprivation and health in Scotland. Health Bull (Edinb). 1990;48(4):162-75.

12. Clark JD, Mossey PA, Sharp L, Little J. Socioeconomic status and orofacial clefts in Scotland, 1989 to 1998. Cleft Palate Craniofac J. 2003;40(5):481-5.

13. Durning P, Chestnutt IG, Morgan MZ, Lester NJ. The relationship between orofacial clefts and material deprivation in Wales. Cleft Palate Craniofac J. 2007; 44(2):203-7.

14. Poletta FA, Castilla EE, Orioli IM, LopezCamelo JS. Regional analysis on the occurrence of oral clefts in South America. Am J Med Genet A. 2007;143A(24):3216-27.

15. Vieira AR, Karras JC, Orioli IM, Castilla EE, Murray JC. Genetic origins in a South American clefting population. Clin Genet. 2002;62(6):458-63.

16. Corach D, Lao O, Bobillo C, van Der Gaag K, Zuniga S, Vermeulen $\mathrm{M}$, et al. Inferring continental ancestry of Argentineans from autosomal, y-chromosomal and mitochondrial DNA. Ann Hum Genet. 2010;74(1):65-76.
17. Wehby GL, Gimenez LG, López-Camelo JS. The impact of unemployment cycles on child and maternal health in Argentina. Int J Public Health. 2017(62):197. doi:10.1007/s00038-016-0857-1.

18. Picket KE, Pearl M. Multilevel analyses of neighbourhood socioeconomic context and health outcomes: a critical review. J Epidemiol Community Health. 2001 Feb;55(2):111-22.

19. Castilla EE, Orioli IM. ECLAMC: the Latin-American collaborative study of congenital malformations. Community Genet. 2004;7(2-3):76-94.

20. Instituto Nacional de Estadística y Censos. Censo Nacional de Población, Hogares y Viviendas 2001.Available at: http: / /www. indec.gov.ar/micro_sitios/webcenso / provincias_2/provincias.asp Accessed 10 May 2016.

21. Instituto Nacional de Estadística y Censos. Pobreza en Argentina. Buenos Aires: INDEC; 1984.

22. Kulldorff M. A spatial scan statistic. Commun Statis Theory Meth. 1997 Jan 1;26(6):1481-96

23. Gadow EC, Paz JE, Lopez-Camelo JS, Dutra MG, Queenan JT, Simpson JL, et al. Unintended pregnancies in women delivering at 18 South American hospitals. NFP-ECLAMC Group. Latin American Collaborative Study of Congenital Malformations. Hum Reprod. 1998;13(7): 1991-5.

24. Chevrier C, Dananche B, Bahuau M, Nelva A, Herman C, Francannet C, et al. 
Occupational exposure to organic solvent mixtures during pregnancy and the risk of non-syndromic oral clefts. Occup Environ Med. 2006;63(9):617-23.

25. Carmichael SL, Ma C, Tinker S, Rasmussen SA, Shaw GM. Maternal stressors and social support as risks for delivering babies with structural birth defects. Paediatr Perinat Epidemiol. 2014;28(4):338-44.

26. Figueiredo RF, Figueiredo N, Feguri A, I Bieski, R Mello, M Espinosa et al. The role of the folic acid to the prevention of orofacial cleft: an epidemiological study. Oral Dis. 2015;21(2):240-7.

27. Little J, Cardy A, Munger RG. Tobacco smoking and oral clefts: a meta-analysis. Bull World Health Organ. 2004;82(3):213-8.

28. Carmichael SL, Nelson V, Shaw GM, Wasserman CR, Croen LA. Socioeconomic status and risk of conotruncal heart defects and orofacial clefts. Paediatr Perinat Epidemiol. 2003;17(3):264-71.
29. Ericson A, Eriksson M, Zetterstrom R. The incidence of congenital malformations in various socioeconomic groups in Sweden. Acta Paediatr Scand. 1984;73:664-6.

30. Yang J, Carmichael SL, Canfield M, Song J, Shaw GM; National Birth Defects Prevention Study. Socioeconomic status in relation to selected birth defects in a large multicentered US case-control study. Am J Epidemiol. 2008;167(2):145-54.

31. Diez Roux AV. Investigating neighborhood and area effects on health. Am J Public Health. 2001 Nov;91(11):1783-9.

32. Reijneveld S. Explanations for differences in health outcomes between neighborhoods of varying socioeconomic level. J Epidemiol Community Health. 2001 Nov 1;55(11):847.

33. Stafford M, Marmot M. Neighborhood deprivation and health: does it affect us all equally? Int J Epidemiol. 2003 Jun 1;32(3): 357-66.
34. Woodhouse C, Lopez Camelo J, Wehby GL. A comparative analysis of prenatal care and fetal growth in eight South American countries. PLoS One. 2014;9(3): e91292.

35. Nyarko KA, Lopez-Camelo J, Castilla EE, Wehby GL. Does the relationship between prenatal care and birth weight vary by oral clefts? Evidence using South American and United States samples. J Pediatr. 2013;162:42-9.

Manuscript received on 28 May 2016. Revised version accepted for publication on 17 November 2016.
RESUMEN

\section{Privación económica individual y regional, $y$ riesgo de hendiduras orofaciales en Argentina}

Objetivo. Analizar los efectos de un bajo nivel socioeconómico individual y una zona geográfica desfavorable en la aparición del labio leporino aislado con o sin paladar hendido ( $L L \pm P$ ) en Argentina.

Métodos. En este estudio de casos y controles se incluyeron 577 recién nacidos con $\mathrm{LL} \pm \mathrm{P}$ aislado y 13344 controles sanos nacidos entre 1992 y 2001, de un total de 546 129 nacimientos ocurridos en 39 hospitales de Argentina. Para identificar las zonas geográficas desfavorables se utilizaron datos del Índice de Necesidades Básicas Insatisfechas. Se calculó un índice de nivel socioeconómico para cada participante usando la edad materna, el número de embarazos, el nivel de instrucción bajo del padre y la madre, y el nivel de ocupación bajo del padre. Se usó regresión logística para evaluar los efectos de un bajo nivel socioeconómico y una zona geográfica desfavorable en la ocurrencia de $\mathrm{LL} \pm \mathrm{P}$.

Resultados. Se observó un riesgo levemente mayor de LL $\pm \mathrm{P}$ en madres con bajo nivel socioeconómico, mientras que una zona geográfica desfavorable no mostró ningún efecto. La ascendencia indígena, las enfermedades agudas maternas y una atención prenatal deficiente fueron factores de riesgo significativos para LL \pm P en madres con bajo nivel socioeconómico, después de ajustar las características demográficas de casos y controles mediante análisis de propensión.

Conclusiones. Un bajo nivel socioeconómico aumentó levemente el riesgo de LL \pm P, pero una zona geográfica desfavorable no mostró ese efecto. No hubo interacción entre un bajo nivel socioeconómico individual y una zona geográfica desfavorable. Los factores relacionados con un bajo nivel socioeconómico individual -inclusive una atención prenatal deficiente, la baja educación de los padres, la falta de información y el estilo de vida- deben abordarse principalmente como factores de riesgo de LL \pm P más que los factores relacionados con una zona de residencia desfavorable.

Palabras clave Labio leporino; fisura del paladar; clase social; Argentina. 
RESUMO Objetivo. Examinar os efeitos do baixo nível socioeconômico individual e área geográfica em situação de carência na ocorrência de fissura labial isolada com ou sem fissura palatina $(\mathrm{FL} \pm \mathrm{P})$ na Argentina.

Carência individual, carência regional e risco de fissuras orais na Argentina

Métodos. Estudo de caso-controle que compreendeu 577 recém-nascidos com FL isolada \pm P e 13344 controles saudáveis, nascidos entre 1992 e 2001, de uma população total de 546129 nascimentos em 39 hospitais na Argentina. Foram usados dados censitários sobre necessidades básicas existentes para estabelecer o grau de carência das áreas geográficas. Foi determinado um índice de nível socioeconômico para cada indivíduo baseado na idade materna, número de gestações, baixa escolaridade materna e paterna e ocupação paterna de baixo nível. Foi realizada uma regressão logística para avaliar os efeitos do baixo nível socioeconômico e área geográfica em situação de carência na ocorrência de FL \pm P.

Resultados. Observou-se um risco discretamente aumentado de FL \pm P em mães com baixo nível socioeconômico, mas nenhum efeito foi verificado quanto à área geográfica em situação de carência. Descendência indígena, doença materna aguda e assistência pré-natal precária foram fatores de risco importantes para $\mathrm{FL} \pm \mathrm{P}$ nas mães com baixo nível socioeconômico, após o uso de escores de propensão para ajustar as características demográficas em casos e controles.

Conclusões. O baixo nível socioeconômico individual foi associado a um discreto aumento do risco de $\mathrm{FL} \pm \mathrm{P}$, mas este efeito não foi observado para área geográfica em situação de carência. Não houve interação entre nível socioeconômico individual e área geográfica em situação de carência. Fatores relacionados ao baixo nível socioeconômico individual, como assistência pré-natal precária, baixa escolaridade dos pais, falta de informação e fatores relacionados aos hábitos de vida, devem ser o foco principal porque eles são os fatores de risco para $\mathrm{FL} \pm \mathrm{P}$, não fatores relacionados ao domicílio em área carente.

Palavras-chave Fenda labial; fissura palatina; classe social; Argentina. 
APPENDIX I. Annual births in ECLAMC hospitals and percentage of total birth population by department/partido in Argentina

\begin{tabular}{|c|c|c|c|c|}
\hline Department/Partido & Province & $\begin{array}{l}\text { Annual births in ECLAMC } \\
\text { hospitals } 2001\end{array}$ & $\begin{array}{l}\text { Total births in department/ } \\
\text { partido in } 2001\end{array}$ & $\begin{array}{l}\% \text { of total births in } \\
\text { ECLAMC hospitals }\end{array}$ \\
\hline CABA & Bs As & 13411 & 42375 & $31.65 \%$ \\
\hline Almirante Brown & Bs As & 2807 & 9199 & $30.51 \%$ \\
\hline Lomas de Zamora & Bs As & 1000 & 10088 & $9.91 \%$ \\
\hline Esteban Echeverría & Bs As & 1878 & 4406 & $42.62 \%$ \\
\hline General San Martin & Bs As & 600 & 6120 & $9.80 \%$ \\
\hline Lanús & Bs As & 1609 & 6461 & $24.90 \%$ \\
\hline Avellaneda & Bs As & 590 & 5691 & $10.37 \%$ \\
\hline General Pueyrredón & Bs As & 4702 & 9675 & $48.60 \%$ \\
\hline La Plata & Bs As & 1311 & 10711 & $12.24 \%$ \\
\hline Gualeguaychu & Entre Ríos & 1045 & 1824 & $57.29 \%$ \\
\hline Paraná & Entre Ríos & 3945 & 5706 & $69.14 \%$ \\
\hline Rosario & Santa Fe & 5631 & 9757 & $57.71 \%$ \\
\hline Capital & Córdoba & 6053 & 20517 & $29.50 \%$ \\
\hline San Martin & Mendoza & 2057 & 2152 & $95.59 \%$ \\
\hline Capital & Mendoza & 1886 & 2002 & $94.21 \%$ \\
\hline Guaymallen & Mendoza & 550 & 4861 & $11.31 \%$ \\
\hline Capital & San Luis & 2677 & 3757 & $71.25 \%$ \\
\hline Posadas & Misiones & 4689 & 6533 & $71.77 \%$ \\
\hline $\begin{array}{l}\text { San Miguel de } \\
\text { Tucumán }\end{array}$ & Tucumán & 10090 & 10372 & $97.28 \%$ \\
\hline Dr. Manuel Belgrano & Jujuy & 2502 & 4919 & $50.86 \%$ \\
\hline Capital & La Rioja & 1730 & 3174 & $54.51 \%$ \\
\hline Futaleufu & Chubut & 1500 & 806 & $186.10 \%$ \\
\hline Bariloche & Rio Negro & 306 & 2075 & $14.75 \%$ \\
\hline Biedma & Chubut & 529 & 1270 & $41.65 \%$ \\
\hline Ushuaia & T. del Fuego & 230 & 956 & $24.06 \%$ \\
\hline
\end{tabular}

APPENDIX II. Propensity scores, which form five strata where socioeconomic variables are similar for cases and controls in each of them; the propensity scores were used to adjust the multivariate logistic analysis

\begin{tabular}{|c|c|c|c|c|c|c|}
\hline \multirow{2}{*}{ Strata } & & Maternal age ${ }^{a}$ & Gravidity $^{b}$ & Maternal education ${ }^{c}$ & Paternal education $^{c}$ & Paternal occupation ${ }^{e}$ \\
\hline & & Mean & Mean & Median & Median & Median \\
\hline \multirow[t]{2}{*}{1} & Controls & 27.9 & 3.6 & 4 & 4 & 4 \\
\hline & Cases & 27.8 & 3.9 & 4 & 4 & 4 \\
\hline \multirow[t]{2}{*}{2} & Controls & 25.0 & 2.7 & 5 & 5 & 5 \\
\hline & Cases & 25.2 & 2.4 & 5 & 5 & 5 \\
\hline \multirow[t]{2}{*}{3} & Controls & 24.1 & 2.7 & 5 & 5 & 5 \\
\hline & Cases & 24.3 & 2.8 & 4 & 4 & 4 \\
\hline \multirow[t]{2}{*}{4} & Controls & 22.9 & 2.8 & 4 & 4 & 3 \\
\hline & Cases & 22.7 & 3.1 & 4 & 4 & 3 \\
\hline \multirow[t]{2}{*}{5} & Controls & 22.6 & 3.0 & 4 & 4 & 3 \\
\hline & Cases & 22.2 & 3.3 & 4 & 4 & 3 \\
\hline
\end{tabular}

a Maternal age (in years).

' Gravidity (number of pregnancies).

${ }^{\mathrm{c}}$ Maternal education and paternal education in 8 categories: 1- no schooling, not read, 2- no schooling, only read,

3- incomplete grammar school, 4- complete grammar school, 5- incomplete secondary school, 6- complete secondary school, 7- incomplete university, 8- complete university. (Maternal and paternal education $<5$ was considered low education.)

d Paternal occupation: 1-unemployed, 2- househusband, 3- odd job/unskilled labor, 4- skilled labor, 5-independent labor,

6- manager, 7- clerk (white collar), 8- professional/university. (Paternal occupation $<5$ was considered low occupation.) 